\title{
Cutaneous Leishmaniasis cases and risk factors in north central of Morocco, Sefrou province: An impact study
}

\author{
Fatima Zahra Talbi $^{1}$,Mohamed $\mathrm{Najy}^{2}$, Nordine Nouayti $^{3}$, Hicham En-nkhili ${ }^{2}$, Abdelhakim El Ouali Lalami ${ }^{4}$ \\ ${ }^{1}$ Laboratory of biochemistry, neurosciences, natural resources and the environment. Faculty of Sciences and Technologies, BP 577 , \\ Hassan First University, Settat, Morocco. \\ ${ }^{2}$ Laboratory of Agro-physiology, Biotechnology, Environment and Quality, Department of Biology, University Ibn Tofail, Faculty of \\ Science, BP133, 14000, Kenitra, Morocco. \\ ${ }^{3}$ Applied Sciences Laboratory, Water and Environmental Engineering Team. National School of Applied Sciences, Al Hoceima. \\ Abdelmalek Essaadi University, Morocco. \\ ${ }^{4}$ Higher Institute of Nursing Professions and Health Techniques of Fez, Regional Health Directorate Fez-Meknes, EL Ghassani \\ Hospital, $30000 \mathrm{Fez}$, Morocco.
}

\begin{abstract}
In order to set up a program for fighting against leishmaniasis disease, it was considered useful beforehand to demonstrate Leishmanian risk factors to the CL disease cases. The Province of Sefrou is among the endemic areas. Surveillance of these outbreaks is essential. This work focused on studying the impact risk factors on the distribution of CL cases. This is a retrospective study of CL cases registered during five years (2007-2010). Statistical analysis was based on one-way analysis of variance (ANOVA) and then the correlation study was carried out (Pearson correlation). A significant linear association was found between the number of CL cases and the population $(\mathrm{r}=0.56 ; \mathrm{p}=0.005)$. This means that the correlation is positive. For the urbanization factor, the association was marked moderately correlated with number of CL cases $(r=0.44 ; p=0.037)$. However, poverty does not influence this distribution; for our study area, this factor is not a risk factor.
\end{abstract}

\section{Introduction}

Leishmaniasis is meant to be a neglected infectious disease though it is considered one of the most common infections among the 2.7 million people living below the poverty eve [1]. They are caused by a protozoan parasite of the genus Leishmania, transmitted by the bite of a vector insect, the sandfly [2]. Nearly 20 species of the genus Leishmania evolving in specific host-parasite systems are pathogenic to humans. They have a significant impact on human health because of the severity of some of their clinical forms, their frequency, and because they affect particularly vulnerable populations. These parasitoses cause different clinical forms in the infected individual; Cutaneous Leishmaniasis (CL), Visceral Leishmaniasis (VL) and Cutaneous Leishmaniasis Mucosal (CLM) [3]. About 350 million people are exposed to leishmaniasis in more than 90 countries in which around 1.5 to 2 million new cases are reported annually [2].

The parasitic cycle of leishmaniasis depends on three main actors: the vector of transmission, the pathogenic parasite and the host. The dynamics of this cycle are conditioned by climatic and socio-economic factors. Leishmaniasis evolve into a Leishmanian pathogenic complex which forms a nosoepidemiological entity specific to each Leishmanian home. In Morocco, the emergence of new outbreaks makes leishmaniasis a public health problem [4,5]. Three clinical entities have been identified: zoonotic CL with L. major transmitted by $P h$. papatasi whose reservoir is a rodent, anthroponotic CL with L. tropica whose vector is $P h$. sergenti and the reservoir which is human being $[6,7]$. For human CL to L. infantumdistributed in northern and southern Morocco [8], its transmission cycle remains unknown. In the Fez Meknes region, two nosological and clinical forms have been identified: VL for $L$. infantum and CL for L. tropica [7, 9]. Between 2000 and 2011, 2843 cases were recorded within a total of 42491 cases recorded in Morocco [10]. Leishmaniases are diseases strongly conditioned by the state of the environment [11], and are sensitive to the climate.

In fact, several studies have confirmed correlations between climatic factors and distribution of leishmaniasis cases[12,13]. In recent decades, climate and environmental changes reported in some endemic regions have contributed to an increase in the number of cases and the spread of the disease [14]. In the same vein, we cannot deny another risk factor, that of Leishmania / HIV co-infections which is an individual factor that promotes the spread of the disease [15].

Human through his activities intervenes in the environment. He can disrupt the natural conditions of proliferation of species following the factor of urbanization, which favors the refuge of reservoirs towards new regions. Still, the demographic increase and 
the unhealthy habitats are also significant in producingfavorable conditions to epidemics and give rise to favorable environments to the proliferation of sandfly vectors [16].The choice of this region as a study area is justified by its vulnerability, its epidemic sensitivenesstoleishmaniasis and by its proximity to other important foci such as that of Taza, Sidi Kacem and Errachidia [17,18,19]. The extension of old foci and the appearance of new ones are linked to the increase in the number of cases.The state of Cutaneous Leishmaniasis disease is widespread in Sefrou Province.

The present work aims to diagnosethe situation of CL diseases in Sefrou Province during the years 2007-2010, by analyzing the impact of urbanization, number of population and rate of poverty on the distribution of this scourge.

\section{Materials and methods}

\subsection{Study zone}

The Province of Sefrou covers an area of $3520 \mathrm{~km}^{2}$ with a predominantly rural population of 259254 inhabitants (Fig.1). It is located between the Saïs plateau and the northern piedmont of the Middle Atlas. From a geographic point of view, it is limited to the South by the Provinces of Boulemane and Ifrane, to the East by the Province of Taza, to the North by the prefecture of Fez, to the West by the Provinces of MoulayYacoub and El Hajeb and to the North-West by the Province of Taounate. Most of these mountainous provinces are endemic and considered to be the home of human CL [20].

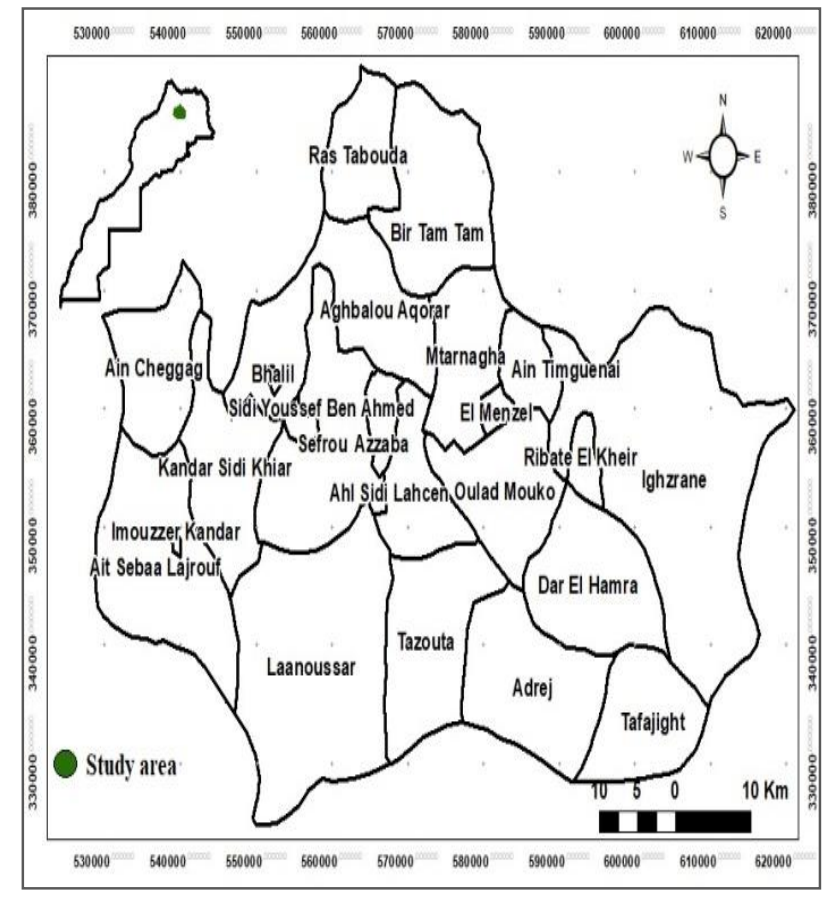

Fig. 1. Presentation of study area Sefrou Province, North Central of Morocco

\subsection{Data resources}

The exploitable data were extracted from the registers of the medical delegation of Sefrou Province. The period of this study lasted for four years, between 2007 and 2010 . The socioeconomic data, namely, poverty rate, population number, and type of environment (urban/rural) were obtained from the High Commissioner for Planningand strategies [21].

\subsection{Data analysis}

In order to meet expectations regarding the understanding of the interactions between the number of CL cases and the various risk factors, we implemented statistical processing on all the data collected. To achieve this goal, the data were entered using a Microsoft Excel 2010 file. The statistical analysis is based on the analysis of variance (ANOVA) then we proceed to the study of the correlation (Pearson correlation) using the software SPSS version 20 statistics. The results are considered significant when $\mathrm{p}$ is less than 0.05 .

\section{Results}

\subsection{The Study of the relationship between risk factors and the distribution of CL cases}

\subsubsection{Impact of the urbanization factor on the distribution of CL cases at the level of SefrouProvince}

Sefrou Province is comprised of seven urban communes and seventeen rural communes. A total of one hundred and twenty-nine cases were verified in the five urban communes of Sefrou Province, with a maximum of cases at the level of El Menzel with sixty-two cases and Sefrou with sixty-one cases. For the rural communes, a number of hundred fifteen cases were recorded with a predominance at the level of the commune of Tazouta with $15.57 \%$ (38 CL cases) percent of CL cases and Ahl Sidi Lahcen with10.65\% (26 CL cases) (Fig. 2).

\subsubsection{Impact of the population on the distribution of CL cases}

According to the population census of the province of Sefrou [17], the number of inhabitants rises to 259254. Based on the number of populations in each municipality, we were able to draw up the distribution map of the population in each municipality (Fig. 3). We notice that the distribution of CL cases according to the number of inhabitants is heterogeneous. Indeed, the communes which are overcrowded are the most infected communes and contain a high number of cases of CL. This is the case for the municipalities of Sefrou and El Menzel. 


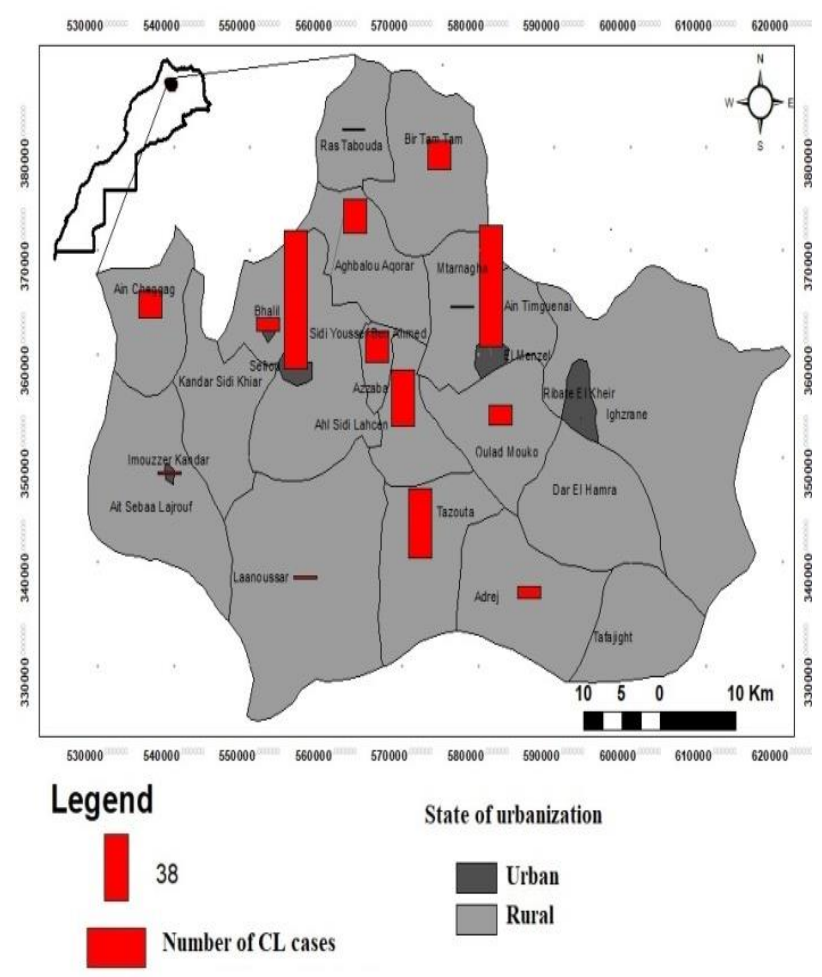

Fig. 2. Distribution map of CL casesat the level of different municipalities in Sefrou Province (2007-2010)

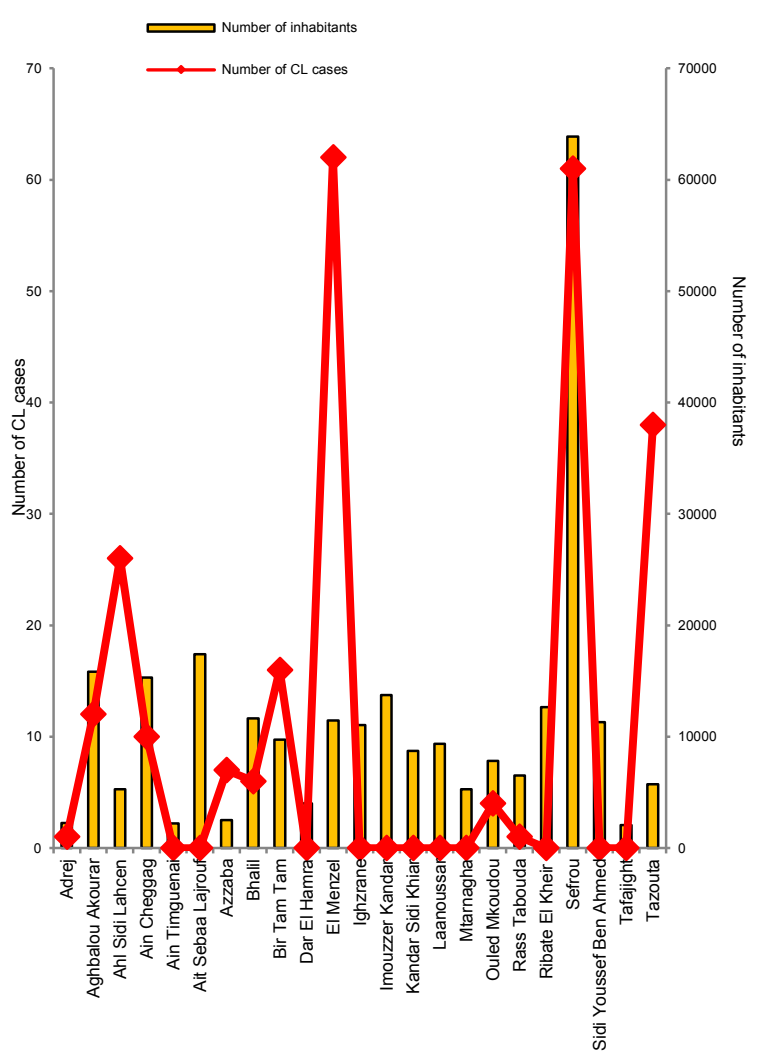

Fig. 3. Distribution of CL cases and the number of inhabitants at the level of different municipalities in the Province of Sefrou (2007-2010)

\subsubsection{Impact of poverty factor on the distribution of CL cases}

According to the data of the High Commission for Planning, the poverty rate at the level of the municipalities of the Province of Sefrou, varies between $5.9 \%$ and $26.4 \%$. The analysis of the results shows that the number of CL cases recorded does not depend on the poverty of the municipalities. Indeed, the two municipalities which recorded the majority of cases: Sefrou with 61 and El Menzel with 62, have a poverty rate of around $8.9 \%$ and $9.6 \%$, while the commune Ahl Sidi Lahcen which recorded 26 cases has a higher poverty rate of $26.4 \%$. Likewise, for the communeAinCheggag only recorded an average of 10 cases despite their very high poverty rate of $25.5 \%$ (Fig.4).

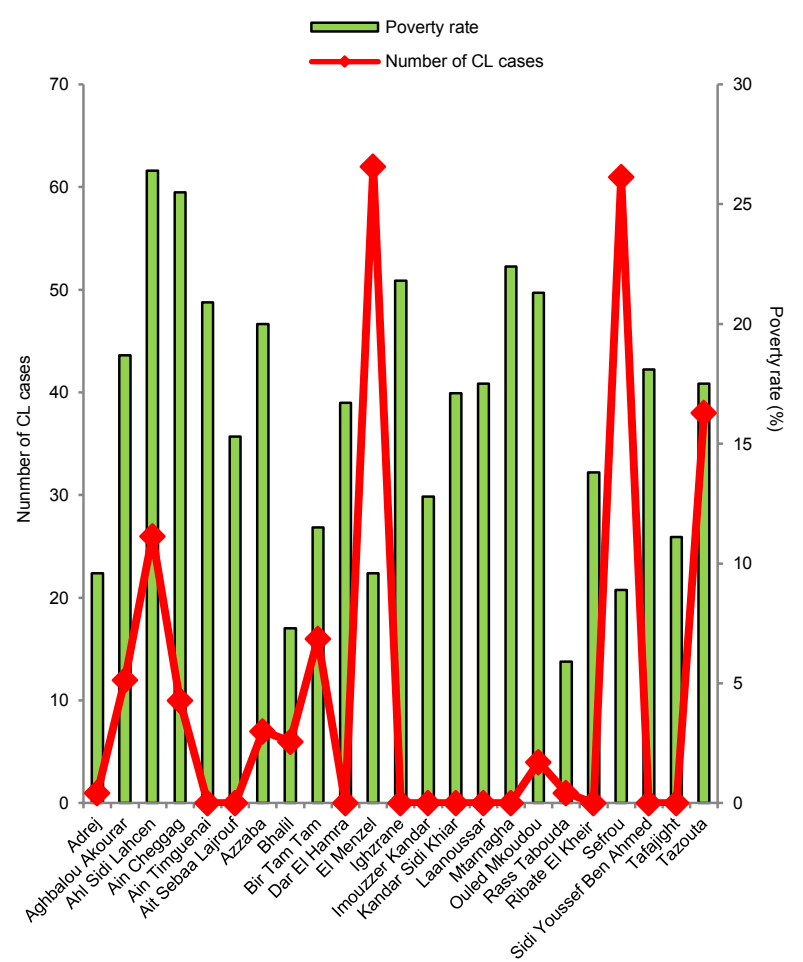

Fig. 4. Distribution of CL cases according to the poverty rate at the level of different municipalities of SefrouProvince (20072010).

\subsection{Statistical analysis}

The Kolmogorov-Smirnova test gives us the statistics of the four studied variables; the number of CL cases has a statistic of 0.285 , degree of freedom 23 and $p$ value at the level of significance 0.00 (Table 1 ). This value below the level of significance pvalue $<0.05$ shows that the number of CL cases does not have a normal distribution 
and the same thing for urbanization and population; Shapiro-Wilknous gives different statistics but with $\mathrm{p}$ value compatible with firsts.

Table. 1. Normality tests

\begin{tabular}{lcccccc}
\hline & \multicolumn{3}{c}{$\begin{array}{c}\text { Kolmogorov- } \\
\text { Smirnov }\end{array}$} & \multicolumn{3}{c}{ Shapiro-Wilk } \\
\cline { 2 - 7 } & $\begin{array}{c}\text { Statis } \\
\text { tic }\end{array}$ & df & $\begin{array}{c}\text { Signific } \\
\text { ation }\end{array}$ & $\begin{array}{c}\text { Statis } \\
\text { tic }\end{array}$ & df & $\begin{array}{c}\text { Signific } \\
\text { ation }\end{array}$ \\
\hline $\begin{array}{l}\text { Number } \\
\text { of CL } \\
\text { cases }\end{array}$ & 0.285 & 23 & 0 & 0.631 & 23 & 0 \\
\hline $\begin{array}{l}\text { Urbanizat } \\
\text { ion }\end{array}$ & 0.479 & 23 & 0 & 0.512 & 23 & 0 \\
\hline $\begin{array}{l}\text { Poverty } \\
\text { rate (\%) }\end{array}$ & 0.109 & 23 & $0.200^{*}$ & 0.972 & 23 & 0.726 \\
\hline $\begin{array}{l}\text { Populatio } \\
\text { n }\end{array}$ & 0.265 & 23 & 0 & 0.564 & 23 & 0 \\
\hline * This is a lower bound of the actual meaning. \\
of signification of Lilliefors. df : the degrees of freedom in the \\
source.
\end{tabular}

As for the poverty rate $(\%)$, we have a pvalue of the order of 0.2 which is above the significance level, so Kolmogorov-Smirnovanous says that there is probably a normal law. The Q-Q diagram Figure (xx) which shows a practically linear cloud which confirms the linearity of the sample.

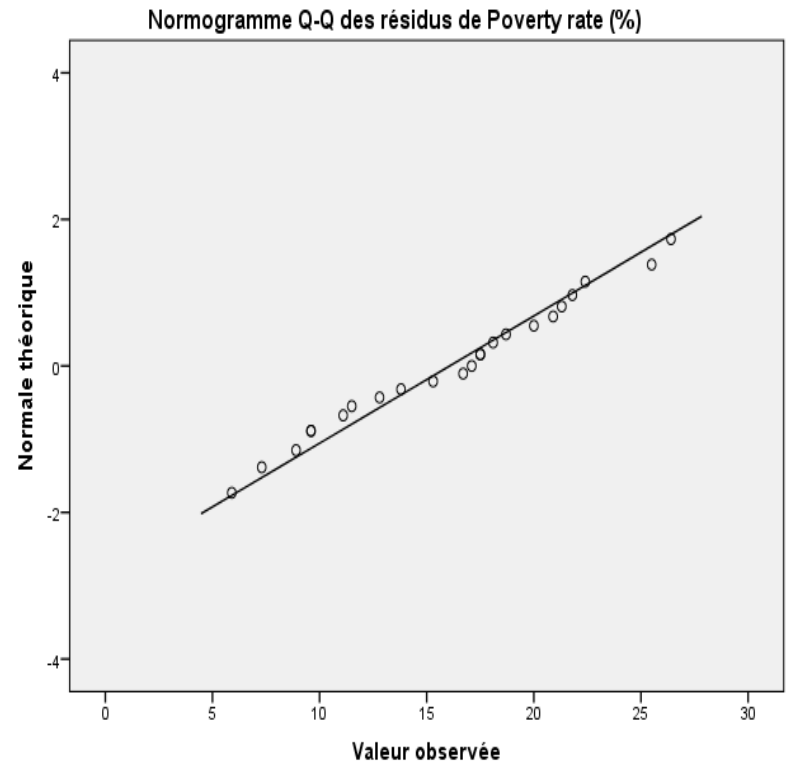

Fig. 5. The Q-Q diagram Figure

To compare the variances of the urbanization variable groups (urban-rural), we test the consistency of the variances of the number of CL cases, number of population and poverty rate $(\%)$ variables on the urbanization groups. Levene's test based on the average of the variables Number of CL cases and Population gives a $p$ value $(0.000$ and 0.001$)<$ at the significance level, which shows that the variance of these variables is not homogeneous in the Urbanization variable groups. For the variable Poverty rate (\%) the homogeneity of variance test gives us a $p$ value of 0.272 which is greater than $5 \%$ so we must conclude that the variance of
Poverty rate $(\%)$ is the same to the urban environment and the rural one (Table 2).

Table. 2. Homogeneity of variance test

\begin{tabular}{|c|c|c|c|c|c|}
\hline & & $\begin{array}{l}\text { Levene's } \\
\text { Statistics }\end{array}$ & df1 & df 2 & Signification \\
\hline \multirow{2}{*}{$\begin{array}{l}\text { Number } \\
\text { of CL } \\
\text { cases }\end{array}$} & $\begin{array}{c}\text { Based } \\
\text { on the } \\
\text { average }\end{array}$ & 33.982 & 1 & 21 & 0 \\
\hline & $\begin{array}{l}\text { Based } \\
\text { on the } \\
\text { median }\end{array}$ & 5.398 & 1 & 21 & 0.03 \\
\hline \multirow{2}{*}{ Population } & $\begin{array}{c}\text { Based } \\
\text { on the } \\
\text { average }\end{array}$ & 14.573 & 1 & 21 & 0.001 \\
\hline & $\begin{array}{l}\text { Based } \\
\text { on the } \\
\text { median }\end{array}$ & 1.846 & 1 & 21 & 0.189 \\
\hline \multirow{2}{*}{$\begin{array}{l}\text { Poverty } \\
\text { rate }(\%)\end{array}$} & $\begin{array}{c}\text { Based } \\
\text { on the } \\
\text { average }\end{array}$ & 1.271 & 1 & 21 & 0.272 \\
\hline & $\begin{array}{l}\text { Based } \\
\text { on the } \\
\text { median }\end{array}$ & 1.474 & 1 & 21 & 0.238 \\
\hline
\end{tabular}

df: the degrees of freedom in the source

We can therefore calculate the correlation coefficients between these four variables using the Pearson and Spearman method.

The linear correlations between these relevant variables make it possible to search for the association by evaluating the degrees of dependence between the different concerned parameters. The evaluation is made using the correlation coefficients determined by statistical calculations (Table 3). The correlation between two parameters will be all the more significant as the correlation coefficient $\mathrm{R}$ will be close to the value 1. Thus, the correlations have been established between all the variables two by two; which allowed us to obtain binary correlation diagrams for interpretations.

The positive correlation between number of CL cases and the population is moderately correlated, with $\mathrm{r}=$ 0.56 , hence an influence of the population on the number of CL cases, at the threshold of $1 \%$ the $p$ value $(0.005)$ is very much lower than $1 \%$. This confirms that there is a significant linear association between these two parameters. Also, the Urbanization shows a moderately correlated association with the number of CL cases; a coefficient of 0.44 is confirmed by the p value $(0.037)$ which is much less than $5 \%$.

No significant correlation between poverty rate (\%) and number of CL cases.

The one-way ANOVA analysis of variance between poverty rate (\%) and the urbanization estimated by the sum of the squares gives an index $F$ of 7.939 which is too large compared to 1 , so the null hypothesis is not likely (Table 4). The $\mathrm{p}$ value which is the probability of observing an index $\mathrm{F}$ with the degree of freedom 3 and 22 greater than 1 is $0.01<0.05$ so we must conclude that there is a significant difference between the two groups (Urban and Rural). 
Table. 3. Correlation Matrix

\begin{tabular}{|c|c|c|c|c|c|}
\hline & & $\begin{array}{l}\text { Numbe } \\
\mathrm{r} \text { of CL } \\
\text { cases }\end{array}$ & $\begin{array}{c}\text { Urbanizatio } \\
n\end{array}$ & $\begin{array}{c}\text { Populatio } \\
n\end{array}$ & $\begin{array}{c}\begin{array}{c}\text { Povert } \\
\text { y rate } \\
(\%)\end{array} \\
\end{array}$ \\
\hline \multirow{3}{*}{$\begin{array}{l}\text { Number of } \\
\text { CL cases }\end{array}$} & $\begin{array}{l}\text { Pearson } \\
\text { correlation }\end{array}$ & 1 & $0.438^{*}$ & $0.564^{* *}$ & $-0,205$ \\
\hline & $\begin{array}{l}\text { Significatio } \\
\mathrm{n} \text { (bilateral) }\end{array}$ & & 0.037 & 0.005 & 0.349 \\
\hline & $\mathrm{N}$ & 23 & 23 & 23 & 23 \\
\hline \multirow{3}{*}{$\begin{array}{l}\text { Urbanizatio } \\
\mathrm{n}\end{array}$} & $\begin{array}{l}\text { Pearson } \\
\text { correlation }\end{array}$ & ,438* & 1 &, $503^{*}$ &,$- 524^{*}$ \\
\hline & $\begin{array}{l}\text { Significatio } \\
\mathrm{n} \text { (bilateral) }\end{array}$ & 0.037 & & 0.015 & 0.01 \\
\hline & $\mathrm{N}$ & 23 & 23 & 23 & 23 \\
\hline \multirow{3}{*}{ Population } & $\begin{array}{l}\text { Pearson } \\
\text { correlation }\end{array}$ &, $564^{* *}$ &, $503^{*}$ & 1 & $-0,257$ \\
\hline & $\begin{array}{l}\text { Significatio } \\
\mathrm{n} \text { (bilateral) }\end{array}$ & 0.005 & 0.015 & & 0.237 \\
\hline & $\mathrm{N}$ & 23 & 23 & 23 & 23 \\
\hline \multirow{3}{*}{$\begin{array}{l}\text { Poverty } \\
\text { rate }(\%)\end{array}$} & $\begin{array}{l}\text { Pearson } \\
\text { correlation }\end{array}$ & $-0,205$ &,$- 524^{*}$ & $-0,257$ & 1 \\
\hline & $\begin{array}{l}\text { Significatio } \\
\mathrm{n} \text { (bilateral) }\end{array}$ & 0.349 & 0.01 & 0.237 & \\
\hline & $\bar{N}$ & 23 & 23 & 23 & 23 \\
\hline
\end{tabular}

* The correlation is significant at the 0.05 level (bilateral)

** The correlation is significant at the 0.01 level (bilateral).

Table. 4. One-factor ANOVA

\begin{tabular}{lccccc}
\hline \multicolumn{5}{c}{ Poverty rate (\%) } \\
\hline & $\begin{array}{l}\text { Sum of } \\
\text { squares }\end{array}$ & df & $\begin{array}{c}\text { Average } \\
\text { of } \\
\text { squares }\end{array}$ & F & Signification \\
\hline $\begin{array}{l}\text { Inter- } \\
\text { groups }\end{array}$ & 199.92 & 1 & 199.92 & 7.939 & 0.01 \\
\hline $\begin{array}{l}\text { Intra- } \\
\text { groups }\end{array}$ & 528.824 & 21 & 25.182 & & \\
\hline
\end{tabular}

Total $\quad 728.744 \quad 22$

$\mathrm{df}$ : the degrees of freedom in the source; F: the F-statistic

\section{Discussion}

Leishmaniasis is currently considered by the WHO to be one of the most neglected diseases in the world. It affects millions of people in the underdeveloped countries. In Morocco, the cutaneous form is declared as a real public health problem $[22,23]$. Our study was made following the emergence CL cases at the level of Sefrou Province; it examines the evolution of the epidemiology of this disease in association with risk factors mentioned in the article. The country of Morocco has followed a strategy to combat this disease and has carried out several information campaigns carried out by the Ministry of Health according to the national authorities [24].

According to the World Health Organization (WHO), one of the main risk factors for leishmaniasis is urbanization, which could be explained by the constant increase in rural migration to urban areas [25]. Our result can be explained by the fact that the increase in anarchic urbanization participates in the production of unhealthy habitats where hygienic conditions are rudimentary. Insanitary housing is a problem which mainly affects rural or peri-urban communities and which is of low socio-economic level [26]. In some cases, immigrants from the margins bring back certain domestic animals and even raise livestock on the spot, which provides a favorable environment to the biological development of sand flies. This discovery was to be a risk factor for leishmaniasis [27-29]. Other studies show that urbanization contributes to the increase ofleishmaniasiscases [30,31]. Thus, the random growth of cities, as well as the lack of control over the quality of the environment, become a major public health problem.

Another factor is that of the increasing density of the population and its relationship with the propagation of environments favorable to the multiplication of the phlebotomy vector [7]. Indeed, Old World anthroponotic cutaneous leishmaniasis (ACL) requires a human reservoir [32,33]. In the event of contamination, overcrowding is directly associated with the high number of $\mathrm{CL}$ cases through the parasite which is transmitted from one subject to another by the bite of the peri-domestic sandfly. Therefore, the human factor can contribute to the extension of the geographic air of the endemic area.

For the poverty factor, at the level of the Province of Sefrou, it was found that there was not a direct link between the poverty rate and the number of CL cases. At the international level, our result is consistent with that of Quebecas an example [34]. At the national and especially regional level, our result also substantiates that of Hajar El Omari. At the level of Meknes, it has been shown that the poverty factor does not influence the distribution of the number of CL cases [35]. Other studies have shown the opposite. In certain regions, poverty is linked to CL disease [36] where the poor constitute the social group most vulnerable to the disease. In leishmanian endemic areas, the risk is strongly correlated with unsanitary housing conditions, environmental sanitation, poor waste recycling and bad economic conditions which create a favorable environment for the proliferation of sandflies [2, 37].

\section{Conclusion}

The study of socio-economic and socio-anthropological approaches makes it possible to take the problem of leishmaniasis as a whole and therefore to eliminate successfully by targeting vector control actions by innovating preventive measures which must be implementedinan interdisciplinary and multidisciplinary manner to avoid any serious health risk. This may be caused by its parasitic infections. This study could be the basis of several studies to be followed as a perspective which fall within the same framework and which targets the same objective of the fight, namely the impact of hygiene and environmental factors, illiteracy. 


\section{References}

1. P.J. Hotez, D.H. Molyneux, A. Fenwick et al., Control of neglected tropical diseases, $\mathrm{N}$ Engl J Med, 357, 1018-27 (2007).

2. WHO, "Control of the leishmaniases," World Health Organ Technical Report Series, vol. XII-XIII, pp. 1186, 2010.

3. R.D. Pearson, A.Q. Sousa, Clinical spectrum of Leishmaniasis,Clin. Infect. Dis., 22, 1-13 (1996).

4. M. Rhajaoui, F. Sebti, H. Fellah, M.Z. Alam, A. Nasereddin, I. Abbasi\& G. Schönian, Identification of the causative agent of cutaneous leishmaniasis in chichaouaProvince ,Morocco, Parasite, 19, 81-84 (2012).

5. WHO, Manuel pour la prise en charge de la leishmaniose cutanée dans la Région OMS de la Méditerranée orientale,(2014).

6. E. Guilvard, J. A. Rioux, M. Gallego et al., LeishmaniatropicainMorocco. III-the vector of Phlebotomussergenti. A propos of 89 isolates, Ann. Parasitol. Hum. Comp., 66, 3, 96-99 (1991).

7. M. Rhajaoui, H. Fellah, F. Pratlong, J.P. Dedet, and M. Lyagoubi, Leishmaniasis due to 260 Leishmaniatropica MON-102 in a new Moroccan focus,Trans. R. Soc. Trop. Med. Hyg., 261 98, 5, 299-301 (2004).

8. J.A. Rioux, G. Lanotte, E. Serres, F. Pratlong, P. Bastien\& J. Périères, Taxonomy of Leishmania, use of isoenzymes. Suggestions for a new classification,Ann. Parasitol. Hum. Comp., 65, 111125 (1990).

9. M. Lakhdar Idrissi,M. S. El OuardiAtmani,M. A.ElarqamBouharrou,M.Hida,Infantile visceralleishmaniasis: about 209 cases Service de pédiatrie, CHU Hassan-II de Fès, Maroc Revue francophone des laboratoires, Février 2011, $n^{\circ}$ 429//55 (2007).

10. Anonym, 2014, Ministère de la santé Marocaine. Santé en chiffres 2013. Edition 2014 [online]Availablefrom :http://www.sante.gov.ma/Pu blications/Etudes_enquete/Documents/Sant\%C3\%A 9enchiffres2013edition2014-.pdf

11. R.V.Ashford, Theleishmaniasis as emerging and reemerging zoonoses, Int. J. Parasitol.,30, 12691281 (2000).

12. A. K.Githeko,S. W. Lindsay\&U. E. Confalonieri,Changement climatique et maladies à transmission vectorielle: une analyse régionale, $\mathbf{4}$, 11 (2001).

13. G. Duvallet, Parasites, vecteurs de pathogènes et changements climatiques. Hydroécologie Appliquée, 15, 87-96,https://doi.org/10.1051/hydro: 2006008 (2006).

14. F.Rodhain, Impacts sur la santé : le cas des maladies à vecteurs. In : Impacts potentiels du changement climatique en France au XXIe siècle, Mission interministérielle de l'effet de 253 serre,
Ministère de l'aménagement du territoire et de l'environnement,Paris,122-127,2000

15. P.Desjeux, B.Piot, K.O’Neill, J.P. Meert,Coinfections à Leishmania /VIH dans le sud de l'Europe, Med. Trop.,61, 187-193, (2001).

16. R. Gonzalez, L. De Sousa, R. Deveraet al.,Seasonal and nocturnal domiciliary human landing/biting behaviour of Lutzomyia(Lutzomyia) evansiand Lutzomyia(Psychodopygus) panamensis (Diptera ;Psychodidae) in a periurban area of a city on the Caribbean coast of eastern Venezuela (Barcelona ; Anzoategui State), Trans. R. Soc. Trop. Med.Hyg., 93, 361-4(1999).

17. M.Hakkour, A.Hmamouch, M.M.El Alem, A.Rhalem, F.Amarir, M.Touzani, A.Sadak, H.Fellah, and F.Sebti, New epidemiological aspects of visceral and cutaneous leishmaniasis in Taza, Morocco, Parasite Vector, 9, 612, DOI 10.1186/s13071-016-1910 (2016).

18. H.El Miri, C.Faraj, O.Himmi, A.Hmamouch, S.Maniar, T.Laaroussi, M.Rhajaoui, F.Sebti and A.Benhoussa, Cutaneous leishmaniasis in Ouazzane and Sidi Kacem provinces, Morocco (1997-2012), Bull. Soc. Pathol. Exot., 109, 5, 376-380(2016).

19. M.M.El Alem, F.Sebti, L.Med, S.Chichaoui, A.El Bachir, K.Habbari, A.Sadak, and H.Fellah, Geographical distribution and new situation of Leishmaniaspecies after the control of cutaneous leishmaniasis foci in Errachidia Province, Morocco, in 2014, Bio. Med. Res. Int. 2016.doi:10.1155/2016/8642373 (2016).

20. M.Rhajaoui, N.Abdelmajeed, H.Fellah, K.Azmi, F.Amrir, A.Al-jawabreh, S.Ereqat, J.Planer, Z. Abdeen,Molecular typing reveals emergence of a newclinic-epidemiologic profile of cutaneous leishmaniasis in Morocco, Emerg.Infect. Dis., 9, 1358-1360 (2007).

21. Haut Commissariat au Plan (HCP) Recensement général de la population et de l'habitat, (2004).

22. Moroccan Ministry of Health. Health in figures 2013-2017. Edition 2014-2018 (2018).

23. Ministry of Moroccan health. (2018). Epidemiology and public health bulletin (July 2018), 56, 76-1, ISSN: 08518238(2016).

24. F.Z. Talbi, F. El Khayyat,H. El Omari,S. Maniar, M. Fadil, A. Taroq, A. JanatiIdrissi, and A. El OualiLalami, Cartography and Epidemiological Study of Leishmaniasis Disease in Sefrou Province (2007-2010), Central North of Morocco, Interdiscip.Perspect.Infect.Dis, Volume 20 20 IArticleID 1867651 I 8 pages I https://doi.org/10.1 155/2020/1867651.

25. WHO, The World Health Report, Geneva: World Health Organization (2004).

26. P.Desjeux, Les leishmanioses, Aspect de santé publique et lutte, Edition Ellipses, 253 (1999).

27. M.A. Ghatee, I. Sharifi, A.A. Haghdoost, Z.Kanannejad, Z. Taabody et al., Spatial 
correlations of population and ecological factors with distribution of visceral leishmaniasis cases in southwestern Iran,J. Vector. Borne. Dis., 50, 3, 179-87 (2013).

28. [28]P.Desjeux, The increase in risk factors for leishmaniasis worldwide, WHO, Mediterr. Zoon. Control. Cent. ,55 (2002).

29. [29] R. Reithinger, M. Mohsen, T. Leslie, Risk factors for anthroponoticcutaneous leishmaniasis at the household level in Kabul, Afghanistan, Plos. Neglect. Trop. D.,4, 639(2010).

30. World Health Organization (WHO), Urbanization: An increasing risk factor for Leishmaniasis, Wkly. Epidemiol. Rec, 77, 365-372 (2002).

31. K. Kahime, S. Boussaa, A. Laamrani-El Idrissi, H. Nhammi, A. Boumezzough, Epidemiological study on acute cutaneous leishmaniasis in Morocco, JADA, http://dx.doi.org/10.1016/j.joad.2015.08.004 (2015).

32. P. Volf, I. Rohousova, P. Cerna, L. Mikes,S. Ozensoy, and Y. Ozbel, Immunogens and enzymes in sandflies and antibody response of bitten hosts (2002).

33. F.Z. Talbi, L. Aarab,C. Faraj, A. JanatiIdrissi,A. El OualiLalami, Monitoring of Vector-borne Diseases: Investigation of Feeding Preferences of the Sand Fly, Phlebotomusperniciosus (Diptera: Psychodidae) in a Focus of Cutaneous Leishmaniasis in Aichoun, North center of Morocco, Int. J. Pharm. Sci. Rev. Res., 41, 2, 48-52 (2016).

34. Desplanques et Piovano, Leishmaniose, maladies sans frontières, Quebec science (2016).

35. H. El Omari, A. Chahlaoui, F. Talbi, K. Ouarrak, and A. El OualiLalami, Impact of Urbanization and Socioeconomic Factors on the Distribution of Cutaneous Leishmaniasis in the Center of Morocco, , Interdiscip. Perspect.Infect.Dis, 2020, Article ID 2196418, 7 pages, 2020. https://doi.org/10.1155/2020/2196418 (2020).

36. A. Oryan, S. Alidadi, and M. Akbari, Risk factors associated with leishmaniasis, Trop. Med. Surg., 3, 2, 1-2 (2014).

37. J. Alvar, S.Yactayo, and C. Bern, Leishmaniasis and poverty, Trends Parasitol. , 22, 12, 552-7 (2006). 